\title{
К.А. Воротынцева
}

Институт филологии СО РАН, Новосибирск

\section{Категория события в аспекте поэтики повседневности (на примере произведений В. Платовой)}

Аннотация: Статья посвящена анализу репрезентации повседневности в художественном произведении и соотношению повседневных структур с центральной категорией теории повествования - событием.

The present article is devoted to an analysis of representation of everyday life in narrative fiction and to a demonstration of the interrelationships between the everyday life structures and the main category of literary theory - the narrative event.

Ключевые слова: мифопоэтика, нарратив, поэтика повседневности, событие, современная русская проза.

Mythopoetics, narrative, poetics of everyday life, event, modern Russian prose.

УДК: 821.161.1.

Контактная информация: Новосибирск, ул. Николаева, 8. ИФЛ СО РАН. Тел. (383) 3304772. E-mail: vorotyntseva@rambler.ru.

Репрезентация структур повседневности в системе художественного повествования - относительно новая область исследования литературной поэтики. Феномен повседневности, попавший в поле зрения гуманитарных наук в начале $\mathrm{XX}$ века, до сих пор является предметом дискуссий - несмотря на, казалось бы, очевидность интерпретации категории повседневности с позиции здравого смысла. Размытость термина и разнообразие трактовок повседневности в философии, социологии, антропологии, фольклоре, порой забывающих ее феноменологическое основание и сводящих повседневность исключительно к бытовому материально-телесному уровню, все же позволяют нам выделить некоторые инвариантные, сущностные черты повседневности. Как целостное жизнебытие и «универсальное поле всякой действительной и возможной практики» [Гуссерль, 2004, с. 193-194], повседневность характеризуется следующими свойствами: 1) тотальностью и неизбежностью - как смысловой базис человеческого бытия; 2) соотнесенностью с определенными культурными образцами, «интерпретационной сеткой», позволяющей субъекту наделять мир смыслом, причем, на «наивном», донаучном уровне; 3 ) своей соотнесенностью с субъектом - повседневность предстает как экзистирующая действительность, как «такая реалия, которая дана человеку (а человек дан ей) целиком, как «нерасчлененная целокупность» (М. Хайдеггер)» [Марковцева, 2006, с. 113].

Трактуемую подобным образом повседневность не стоит смешивать с бытием, которое, если кратко, представляет собой онтос, отделенный от гнозиса, тогда

* Исследование выполнено в рамках НИР «Оптимизация коммуникативных процессов как предмет междисциплинарного исследования», выполняемых на основании государственного контракта № 02.740.11.0370 в рамках Федеральной целевой программы «Научные и научно-педагогические кадры инновационной России». 
как повседневность - это отрефлексированный онтос, онтос плюс гнозис: «то, что cymь вещзи, - вещи, о каких мы только и можем делать высказывания, о бытии и небытии каких, об определенности и инаковости каких мы только и можем спорить, вопрос о каких мы только и можем разумно решать, - то, что суть вещи, они суть как вещи опыта. Не что-либо иное, но лишь опыт предписывает им их смысл» [Гуссерль, 2009, с. 144; курсив автора]. Понимаемая таким образом повседневность предстает в общих чертах как индивидуальный опыт бытия и переживание-объяснение его смысловых структур.

В литературоведческих работах, посвященных поэтике повседневности, пик интереса к которой приходится на последние годы, не выработалось скольконибудь единого мнения в понимании феномена повседневности (наиболее частотным является просто нерефлективное упоминание или приравнивание повседневности к быту, к жестокой неприкрашенной реальности, прозе жизни [Кузьмина, 2004 , с. 65]); также нерешенным остается вопрос о том, на каком уровне художественного целого можно обнаружить «следы присутствия» повседневности. Актуальность данного исследования состоит в попытке немного пролить свет на это «белое пятно» литературной теории и предложить один из возможных способов исследования поэтики повседневности - через сопоставление художественнообразных структур повседневности с нарратологической категорией события. Для исследования была выбрана современная литература, поскольку она в своей жанровой неустойчивости и размытости являет смешение ансамблей текстов и дискурсов - нередко даже в пределах одного произведения [Силантьев, 2006] - и эта полифония дает возможность проследить реализацию самых разнообразных моделей повседневности. Если точнее, объектом нашего исследования стали произведения Виктории Платовой (псевдоним Виктории Евгеньевны Соломатиной), а именно тот корпус текстов, который относится к последним, не детективным книгам писательницы, выполненным, скорее, в жанре «магического реализма». Таким образом, мы опираемся на 5 книг, вышедших с 2005 по 2009 год: «Ужасные невинные» (2005), «После любви» (2006), «Тингль-Тангль» (2006), «Вуе-bуе, baby!..» (2007), «Из жизни карамели» (2009). Предметом нашего исследования является репрезентация модели повседневности в структуре художественного текста и соотношение этой модели с центральной категорией нарратологии - событием.

В философских концепциях повседневность предстает как некое бытие сознания, как самоощущение и самообъективация субъекта в мире. Как следует из подобного понимания повседневности, его «интенциональная структура... может быть проявлена в смысловой структуре бытия» [Марковцева, 2006, с. 115]. Рискнем предположить, что аналогичным образом повседневность в пространстве художественного текста может реализовываться в ценностно-смысловой структуре мира произведения. Именно в особым образом организованной действительности героя, в бытийной структуре «ценностного уплотнения» вымышленного мира вокруг «ценностного центра» произведения [Бахтин, 1979, с. 163] следует пытаться разглядеть репрезентацию моделей повседневности. Чтобы поймать эти ускользающие от исследовательского взгляда явления, мы предлагаем соотнести текстуально оформленные структуры повседневности с важнейшей категорией теории повествования - событием. Подобный путь представляется нам целесообразным, поскольку действительность героя, то есть внутренний мир произведения, состоит из ряда событий, образующих фабульное действие и на сюжетном уровне наделяющихся актуальным смыслом - и тип этих событий, как утверждается исследователями, неизбежно связан со свойствами изображенного мира [Бахтин, 1975]. Как мы попробуем показать, именно определенный тип повседневности соотносится с характером возможных и невозможных событий в повествовании. 
Категория события является ключевой в теории повествования - как известно, особенность нарратива состоит в его двоякой событийности: соотношение референтного события (события, о котором рассказывается, то есть истории) и события рассказывания (дискурсии) являют произведение в его событийной полноте: «Мы воспринимаем эту полноту в ее целостности и нераздельности, но одновременно понимаем и всю разность составляющих ее моментов» [Бахтин, 1975, с. 403-404]. В определении события, между тем, не существует единого мнения: наиболее распространен взгляд на событие как на нечто внеочередное, неожиданное, нетривиальное [см. например: Шмид, 2008, с. 22], как на отклонение от нормы, игру случая. Понимая, что подобная трактовка события является чересчур расширительной, ряд исследователей вводит дополнительные признаки: Ю.М. Лотман определяет событие как «перемещение персонажа через границу семантического поля» [Лотман, 1970, с. 282], Н.Д. Тамарченко трактует событие как переход от одной ситуации к другой в результате активности персонажа [Тамарченко, 1999, с. 80]. В. Шмид наделяет событие пятью признаками: основными критериями - релевантностью, непредсказуемостью, а также дополнительными консекутивностью, необратимостью, неповторяемостью [Шмид, 2008, с. 25-27]. Более генерализированное определение события приводит В.И. Тюпа: согласно его концепции событие обладает тремя аспектами. Во-первых, оно гетерогенно, то есть представляет собой актантный фактор вторжения, «прерывающий, искажающий, трансформирующий естественную или нормативную последовательность состояний, ситуаций, действий» [Тюпа, 2002, с. 22]. Во-вторых, событие хронотопично, то есть обладает определенными пространственно-временными характеристиками [Там же, с. 23]. В-третьих, оно умопостигаемо, интеллигибельно, то есть получает свой статус только от субъекта, актуализатора события: без его смыслообразующей интенции «никакая фактичность еще не событийна» [Там же, c. 21].

Для повествования событие, как мы уже говорили, является ключевой категорией: нарратив образуется именно цепью событий. Однако, как отмечается в работах по исторической поэтике, литературе известны не только событийные тексты: существует определенный ряд явлений, сводящих мир эксцессов и аномалий, окружающих человека, к норме и устройству [Лотман, 1992, с. 225]. Так, мифологические конструкты, которые по сути анарративны, так как проживаются, а не рассказываются, характеризуются тем, что фиксируют принцип, закономерный ход событий, а не случай [Там же, с. 232]. Миф не событиен в том смысле, что он целостен, а не фрактален, и объемлет собой все значимые оппозиции - например, праздник-будни, в которой праздник предстает эксцессом, не разрушающим миф, а имеющим космогонический характер и ведущим к смерти старого мира и рождению нового [Кайуа, 2003, с. 227]. В рамках мифа не существует противопоставления события и повседневности, «вся сплошь повседневность состоит здесь из действенного воспроизведения космической жизни» [Фрейденберг, 1997, с. 5253], любой эксцесс предусмотрен мифом, включен в повседневность, поэтому литература, тяготеющая к мифу, в той или иной степени реализует модель повседневности, которую условно можно назвать «сакрализованной». В этом типе повседневности любое событие или эксцесс предусмотрены, предопределены, поэтому противопоставление повседневность-событие для нее оказывается нехарактерным: примеры реализации подобной модели повседневности дает нам древняя литература. Ее генезис и взаимоотношения с конструктами мифа не входят в задачу нашего исследования, отметим только, что событие в современном понимании появляется в литературе далеко не сразу: например, в эпоху синкретизма событием в сюжете являлся переход через топологическую границу отдельных форм [Теория литературы, 2007, с. 53]. Таким образом, для «сакрализованной» повседневности, воплощенной в соответствующей структуре мира произведений, характерны цельность, полнота и невозможность осуществления события в со- 
временном понимании: повседневностью не предусмотрен акт, который бы ее разрывал, поскольку он заранее включен в саму структуру мира - даже преступления, которые нарушают священные табу, предусмотрены, ибо являются механизмом для получения сверхчеловеческих способностей, уже заложенным в модели данного мира.

Это один предел, к которому может стремиться репрезентация повседневности в художественном произведении. Второй предел представляет собой тот воплощенный в тексте тип повседневности, который нам наиболее привычен и знаком - когда структурой мира произведения допускается существование события в значении отклонения от нормы или ритуала. Вокруг такого события, являющегося «зерном сюжетного повествования» [Лотман, 1992, с. 226], и строится литература в ее современном значении. Более того, подобное событие можно рассматривать как разрушающее, разрывающее повседневность мира произведения, поскольку оно вносит в его смысловую структуру нечто необъяснимое, внешнее, не включенное в нее - то есть некий неинтегрированный в повседневность компонент. Мы предлагаем дать подобной модели повседневности условное название «профанной», поскольку разобщенность и неполнота - а событие в данном случае имеет характер разрыва - свойственны именно профанному миру, который, в отличие от сакрального, не в состоянии снять все противоречия, не всегда и не все может объяснить своими средствами и в этом смысле является бледной тенью «тонкого» мира, «ибо только сакральное существует абсолютно» [Элиаде, 1998, c. 24 ; курсив автора]. Нередко под событием, разрушающим подобную повседневность, выступает вторжение в мир произведения неких трансцендентных сил, что выражается либо в виде нравственных рефлексий, изменений и перерождений героя (подобный тип события особенно характерен для русской литературы XIX века - вспомним нравственное преображение Родиона Раскольникова), либо может принимать вид сверхъестественных вмешательств. В целом, данный тип повседневности реализуется таким способом, что на уровне смысловой структуры текста ему противостоит событие - как то, что в силах разрушить эту повседневность.

Таким образом, мы имеем два предела, к которым стремится литература к полнейшей бессобытийности, к типу «сакрализованной» повседневности, объясняющей все противоречия и включающей их в одно целое (что характерно для мифа, который оказывает влияние на подобный тип литературы); второй предел это художественные нарративы нового времени, ориентированные на событийность и реализующие «профанную» модель повседневности, которой противостоит и которую разрушает событие. Можно сказать, что это две крайности, между которыми существует множество причудливых вариантов. Рассмотрим один из них на примере реализации модели повседневности в произведениях В. Платовой.

В текстах писательницы ключевыми событиями, развертывающими фабулу, становятся явления, которые носят характер необъяснимых случайностей. Именно они являются опорными точками повествования. Приведем несколько примеров: герой случайно сбивает на трассе незнакомого человека, у которого в мобильном телефоне оказываются фотографии девушки, которую герой тщетно пытается найти, что становится важным моментом для построения дальнейшей фабульной цепи событий; кроме того, некий неизвестный и так и остающийся нераскрытым адресант посылает герою письма-наводки, подсказывая, что делать дальше и направляя его («Ужасные невинные»); внутри купленной на рынке рыбы обнаруживается ключ, счастливым образом открывающий нужную героине дверь («После любви»); героиня внезапно из ниоткуда получает дар - невероятные способности в приготовлении пищи, целиком изменяющие течение ее жизни («ТингльТангль»); герой получает на мобильный телефон (даже неработающий) смсподсказки, приходящие от несуществующего оператора PGN («Из жизни карамели») и содержащие указания насчет того, как ему следует действовать в той или 
иной (часто даже еще не наступившей) ситуации. Не вдаваясь в подробности, отметим, что именно в этом состоит существенное отличие анализируемых произведений Платовой от детектива, в котором, как известно, фабульное действие не может строиться на удивительных совпадениях и случайностях [Ван Дайн, 1990].

Вторжение элемента чудесного в имманентно-реальный мир в произведениях Платовой обычно происходит благодаря абстрактной неперсонифицированной силе: как, например, нечто безликое и всезнающее, что периодически появляется в чате под ником јukebox, означающим автомат, проигрывающий музыку, и подбрасывает подсказки герою («Ужасные невинные»). Гораздо реже сверхъестественные силы наделяются актантной функцией и принимают вид персонажей пусть и не антропоморфных - как случайно оказавшийся у героини кот («Вуe-bye, baby!..»), принесший с собой элемент «чего-то не совсем обычного, но, несомненно, чудесного и радостного» [Платова, 2007, с. 131] и иррациональными способами изменивший жизнь своей новой хозяйки. Вмешательство сверхъестественного в текущую цепь событий совершенно не смущает ни повествователя, ни героев: это воспринимается ими как нечто непротиворечивое, вполне допустимое рамками окружающей их повседневности. Даже когда «все совсем не как всегда» [Платова, 2009, с. 331; курсив автора], герои мало рефлектируют по этому поводу наоборот, как ни в чем не бывало, пользуются открывшимися возможностями мира. Вторжение сверхъестественного, трансцендентного не вызывает у них удивления: необъяснимое органически встраивается в повседневность - квинтэссенцией этого слияния становится появление в последнем романе откровенно сказочного персонажа - дракона («Из жизни карамели»), чью хтоническую образность мы здесь не будем затрагивать.

Таким образом, произведения В. Платовой характеризуются вмешательством в фабульное действие неких сверхъестественных, потусторонних, трансцендентных сил, однако в рамках смысловой структуры мира данных произведений этому вторжению не придается статус события: необъяснимые случайности не вызывают удивления у персонажей и спокойно встраиваются в повседневность фикционального мира. Более того - именно благодаря явлению высших сил и происходит развитие фабулы, опирающейся в ключевых моментах на те события, насчет которых герой может спокойно и даже с облегчением констатировать - «я не могу найти объяснения ничему» [Платова, 2005, с. 106]. Репрезентированная в текстах повседневность обнаруживает устойчивость к вторжению трансцендентного: вмешательство высших сил оказывается не в состоянии разрушить, разорвать повседневность, обрести статус события - более того, их явление становится фактором, конституирующим смысловой строй мира. Таким образом, в произведениях Платовой мы видим модель повседневности, представляющей собой некий промежуточный между обозначенными нами пределами вариант - повседневность в ее текстах удивительным образом сохраняет целостность при вторжении сверхъестественного и интегрирует элемент «чудесного» в свою структуру.

Изучение репрезентации повседневности в художественных текстах является интересной и пока только находящейся в стадии разработки областью литературной поэтики. Наше исследование - это скромная попытка предложить один из возможных взглядов на проблему анализа поэтики повседневности, методов ее изучения и не допустить при этом недооценки важности «единственно действительного, действительно данного в восприятии, познанного и познаваемого в опыте мира - нашего повседневного жизненного мира» [Гуссерль, 2004, с. 74]. 


\section{Литература}

Бахтин М.М. Формы времени и хронотопа в романе. Очерки по исторической поэтике // Бахтин М.М. Вопросы литературы и эстетики. М, 1975. С. 234 407.

Бахтин М.М. Эстетика словесного творчества. М., 1979.

Ван Дайн С.С. Двадцать правил для писания детективных романов // Как сделать детектив. М., 1990.

Гуссерль Э. Кризис европейских наук и трансцендентальная феноменология. Введение в феноменологическую философию. СПб., 2004.

Гуссерль Э. Идеи к чистой феноменологии и феноменологической философии. М., 2009.

Кайуа Р. Миф и человек. Человек и сакральное. М., 2003.

Кузьмина Т.Д. «Поэзия и правда» повседневности в «Былом и думах» А.И. Герцена // Пушкинские чтения - 2004. Повседневность как текст культуры: материалы международной научной конференции «Филология в XXI веке: проблемы и методы исследования». СПб., 2004. С. 64-70.

Лотман Ю.М. Структура художественного текста. М., 1970.

Лотман Ю.М. Статьи по семиотике и топологии культуры. Таллинн, 1992. T. 1.

Марковцева О.Ю. Повседневность как бытие человека в мире // Вестник Оренбургского государственного университета. 2006. Т. 1. № 6. С. 111-117.

Платова В. Ужасные невинные. М., 2005.

Платова В. Вуе-bye, baby!.. М., 2007.

Платова В. Из жизни карамели. М., 2009.

Силантьев И.В. Газета и роман: Риторика дискурсных смешений. М., 2006.

Тамарченко Н.Д. Событие // Литературоведческие термины. Коломна, 1999. Вып. 2. С. 79-81.

Теория литературы: В 2 т. / под ред. Н.Д. Тамарченко. М., 2007. Т. 2: Бройтман С.Н. Историческая поэтика.

Тюпа В.И. Очерк современной нарратологии // Критика и семиотика. 2002. Вып. 5. С. 5-31.

Фрейденберг О.М. Поэтика сюжета и жанра. М., 1997.

Шмид В. Нарратология. М., 2008.

Элиаде М. Миф о вечном возвращении. СПб., 1998. 